\title{
Characterization of regulatory $T$ cells in patients with B-cell chronic lymphocytic leukemia
}

\author{
KRZYSZTOF GIANNOPOULOS ${ }^{1,3}$, MICHAEL SCHMITT ${ }^{1}$, MALGORZATA KOWAL ${ }^{2}$, PAULINA WLASIUK ${ }^{2}$, \\ AGNIESZKA BOJARSKA-JUNAK ${ }^{3}$, JINFEI CHEN ${ }^{1}$, JACEK ROLINSKI ${ }^{3}$ and ANNA DMOSZYNSKA ${ }^{2}$ \\ ${ }^{1}$ Department of Internal Medicine III, University of Ulm, 89081 Ulm, Germany; Departments of \\ ${ }^{2}$ Hematooncology and ${ }^{3}$ Clinical Immunology, Medical University of Lublin, 20-950 Lublin, Poland
}

Received April 9, 2008; Accepted May 8, 2008

DOI: $10.3892 /$ or_00000059

\begin{abstract}
The status of the immune system of patients with B-cell chronic lymphocytic leukemia (B-CLL) is not yet sufficiently characterized. Clinically, B-CLL patients present immunodeficiency increasing along with disease progression and signs of autoimmunity. In the current study, we evaluated the expression of FOXP 3 in $\mathrm{CD} 4{ }^{+} \mathrm{CD} 25^{\text {hi }} \mathrm{T}$ regulatory lymphocytes (Treg) and their influence on immune response against tumor and viral antigens in the complex system of peripheral blood mononuclear cells. In 80 B-CLL patients, the frequency of Treg $\left(C D 4{ }^{+} C D 25^{\text {hi }}\right.$ $\mathrm{FOXP}^{+}$) cells was significantly higher in B-CLL patients when compared to healthy volunteers (HV) and increased with the progression of the disease (median: $8.24 \%$ in stage A, $11.24 \%$ in stage B and $12.57 \%$ in stage C according to the Binet classification). The frequency of Treg showed no correlation with prognostic markers such as ZAP-70, CD38 and HLA-G. Notably, Treg frequency correlated with serum levels of TNF $\left(r^{2}=0.45, p=0.001\right)$. T-cell immune responses against epitopes derived from the tumor-associated antigens survivin, fibromodulin and RHAMM as well as from the influenza matrix protein were evaluated. Functionally, higher frequencies of Treg correlated with decreased T-cell responses against viral and tumor antigens. In conclusion, we detected higher frequencies of Treg in B-CLL patients than in HV. Furthermore, Treg constitute the crucial mechanism of immunosuppression in B-CLL patients.
\end{abstract}

\section{Introduction}

The immune status of patients with B-cell chronic lymphocytic leukemia (B-CLL) is poorly characterized $(1,2)$. Clinically,

Correspondence to: Dr Krzysztof Giannopoulos, Department of Clinical Immunology, Medical University of Lublin, Jaczewskiego 8, 20950 Lublin, Poland

E-mail: krzysztof.giannopoulos@alumni.uni-ulm.de; giannop@tlen.pl

Key words: B-cell chronic lymphocytic leukemia, regulatory T cells, tumor-associated antigens, cytotoxic $\mathrm{T}$ lymphocytes, receptor for hyaluronic acid-mediated motility, survivin, fibromodulin
CLL patients present immunodeficiency, along with signs of autoimmunity (3). Several studies have aimed to characterize the immunity of B-CLL, however, results were ambiguous and difficult to interpret especially towards active immunotherapy for those patients (4). The graft vs. leukemia effect (5) as well as the 'spontaneous' remissions associated with an increased immunity against viral antigens (6) suggest that CLL cells may be targeted by a T cell-mediated immune response. Naturally occurring tumor-reactive $\mathrm{T}$ cells were found in some B-CLL patients (7). During disease progression, patients displayed signs of immunosuppression resulting in an impaired immune response against tumor-associated antigens (TAA) as well as against viral and bacterial antigens. Several immunosuppressive mechanisms allow CLL cells to escape from immunosurveillance. Recently, enhanced frequencies of $\mathrm{CD} 4{ }^{+} \mathrm{CD} 25^{\text {hi }} \mathrm{T}$ regulatory cells (Treg) in B-CLL were reported by Beyer et al (8). Apart from $\mathrm{CD} 4{ }^{+} \mathrm{CD} 25^{\text {hi }} \mathrm{T}$ cells, other immunomodulatory factors such as cytokines IL-10 and TGF- $\beta$ may suppress immune responses $(9,10)$. Defects of immune response might be induced by a direct cell-cell contact suggesting the immunosuppressive role of the B-CLL cell itself that might be mediated by the expression of the non-classic human leukocyte antigen (HLA)-G protein (11). HLA-G released in its soluble (sHLA-G) form may also inhibit immune responses against TAA since sHLA-G inhibits the function of $\mathrm{T}$ as well as NK cells leading to tumor progression (12).

Tumor progression promoted by an elevated frequency of Treg was also reported for other carcinomas $(13,14)$. The addition of $\mathrm{CD} 4+\mathrm{CD} 25^{\text {hi }}$ cells to a mixed lymphocyte reaction (MLR) resulted in a decreased antigen recognition by $\mathrm{T}$ cells $(8,15)$, which clearly proved the potency of Treg in suppressing T-cell responses $(8,16)$. The single addition of Treg to an immunosuppressive assay was able to confirm their inhibitory potential. However, little is known about the role of Treg in the more complex system of peripheral blood (PB). Treg are considered as key immunomodulatory cells of the immune system. The forkhead family transcription factor, FOXP3, is critically important for the development and function of Treg (17). In this study, the expression of FOXP3 was assessed in $\mathrm{CD}^{+}$cells from the $\mathrm{PB}$ of patients with $\mathrm{B}-$ CLL. Furthermore, we wanted to characterize the role of Treg in the specific $\mathrm{T}$-cell response against tumor and viral antigens in a complex system containing a whole population of 
mononuclear cells of B-CLL patients. We therefore evaluated T-cell-mediated immune responses against HLA-A2-restricted epitopes of survivin, a member of the antiapoptotic protein family as well as recently defined epitopes derived from fibromodulin and RHAMM (18-20).

Recently, Valencia et al (21) reported that TNF inhibited the suppressive function of Treg in patients with rheumatoid arthritis (RA). The exact role of TNF in the regulation of Treg function remains to be elucidated. Therefore, we assessed the expression of Treg by TNF as well as TNF receptors, since it was shown that elevated levels of TNF were associated with progressive disease in B-CLL patients. Moreover, based on results obtained in RA, one might speculate on a decreased Treg frequency as well as the function in advanced stage CLL patients with elevated TNF levels (22).

\section{Materials and methods}

Cell samples. Samples were taken from 80 previously untreated B-CLL patients admitted to the Department of Hemato-oncology, Medical University of Lublin. This study was approved by the Local Ethics Committee (KE-0254/178/ 2006). The peripheral blood samples were taken from 10 healthy volunteers (HVs; age range: 25-75 years, mean: 56 years; 6 male and 4 female). Informed consent was obtained from all patients and HVs with respect to the use of their blood for scientific purposes. Thirty-three patients were classified in stage A, 28 in B and 19 in C according to the Binet classification (mean age: 63 years, range: 37-93). The clinical characteristics of the patients are summarized in Table I. No autoimmune effects such as autoimmune hemolytic anemia or autoimmune thrombocytopenia were observed in these patients.

Cell isolation. Peripheral blood mononuclear cells (PBMC) were isolated by Ficoll density gradient centrifugation. The viability of obtained PBMC was always $>95 \%$, as determined by trypan blue staining. Viable cells were quantified in a Neubauer chamber (Zeiss, Oberkochen, Germany) and stored in liquid nitrogen for FACS analysis and functional assays.

Peptides. Based on our previous studies $(18,23)$, the RHAMMderived HLA-A2 restricted the $\mathrm{CD} 8^{+} \mathrm{T}$ cell epitope $\mathrm{R} 3$ (pos. 165-173; ILSLELMKL) and was chosen as an immunogenic peptide in B-CLL. Fibromodulin- and survivin-derived peptides FMOD (pos. 250-259; YMEHNNVYTV) and SUR (pos. 97-106 ELTLGEFLKL) were selected based on published data $(19,20)$. As a viral peptide, the influenza matrix protein (IMP)-derived peptide (GILGFVFTL) was used. Peptides were synthesized by Thermo Electron Corporation (Ulm, Germany) with a minimum of $95 \%$ purity as measured by high performance liquid chromatography (HLPC). All peptides were HLA-A2 restricted.

Mixed lymphocyte peptide culture (MLPC) and interferon (IFN)- $\gamma$ ELISpot assay. PBMC from HLA-A2-positive B-CLL patients were thawed with a yield of $>95 \%$ viable cells and subsequently left for $24 \mathrm{~h}$ of resting period in the culture medium containing RPMI-1640, supplemented with a $10 \%$ FCS serum (Biochrom AG, Berlin, Germany). The following
Table I. Basic characteristics of 80 B-CLL patients.

\begin{tabular}{|c|c|}
\hline Characteristics & Patients (n) \\
\hline \multicolumn{2}{|l|}{ Sex } \\
\hline Male & 50 \\
\hline Female & 30 \\
\hline \multicolumn{2}{|l|}{ Age } \\
\hline $40-49$ & 5 \\
\hline $50-59$ & 23 \\
\hline $60-69$ & 25 \\
\hline $70-79$ & 26 \\
\hline$>80$ & 1 \\
\hline \multicolumn{2}{|l|}{ Binet stage } \\
\hline A & 33 \\
\hline B & 28 \\
\hline $\mathrm{C}$ & 19 \\
\hline \multicolumn{2}{|c|}{ Lymphocytosis (G/L) } \\
\hline$<20$ & 16 \\
\hline $20-50$ & 25 \\
\hline$>50$ & 39 \\
\hline \multicolumn{2}{|c|}{ ZAP-70 (cut-off 20\%) } \\
\hline Positive & 43 \\
\hline Negative & 46 \\
\hline Not available & 3 \\
\hline \multicolumn{2}{|c|}{ CD38 (cut-off 30\%) } \\
\hline Positive & 58 \\
\hline Negative & 16 \\
\hline Not available & 6 \\
\hline
\end{tabular}

day, cells were counted, placed in a 6-well plate and pulsed with R3, FMOD, IMP or SUR peptides at a concentration of $20 \mu \mathrm{g} / \mathrm{ml}$, or without peptide as a negative control, respectively. The MLPC was supplemented with $10 \mathrm{U} / \mathrm{ml}$ IL-2 (human interleukin-2, Sigma-Aldrich, Munich, Germany) and $20 \mathrm{ng} / \mathrm{ml}$ IL-7 (recombinant, human interleukin-7, Strathmann Biotec AG, Hamburg, Germany) on day +1 . On day +7 of MLPC, cells were harvested and evaluated for their specific cytotoxicity in an ELISpot assay with IMP, R3, FMOD and SUR peptides, with the unspecific positive control pokeweed mitogen (PWM) (Sigma-Aldrich) or without a peptide, as a negative control as described in detail earlier (18). ELISpot assays were performed as described elsewhere (24) to determine the specific secretion of IFN- $\gamma$ against R3, FMOD, SUR or IMP-positive target cells according to the manufacturer's instructions (Mabtech AG, Nacka, Sweden). ELISpot assays were performed under the conditions recommended by the Cancer Immunotherapy (C-IMT) Monitoring Panel to which our institutions contributed (25).

FACS analysis of regulatory T cells (Treg). PBMC from BCLL patients were thawed with RPMI-1640 containing DNA-ase (Sigma-Aldrich) with a yield of $>95 \%$ viable cells. 

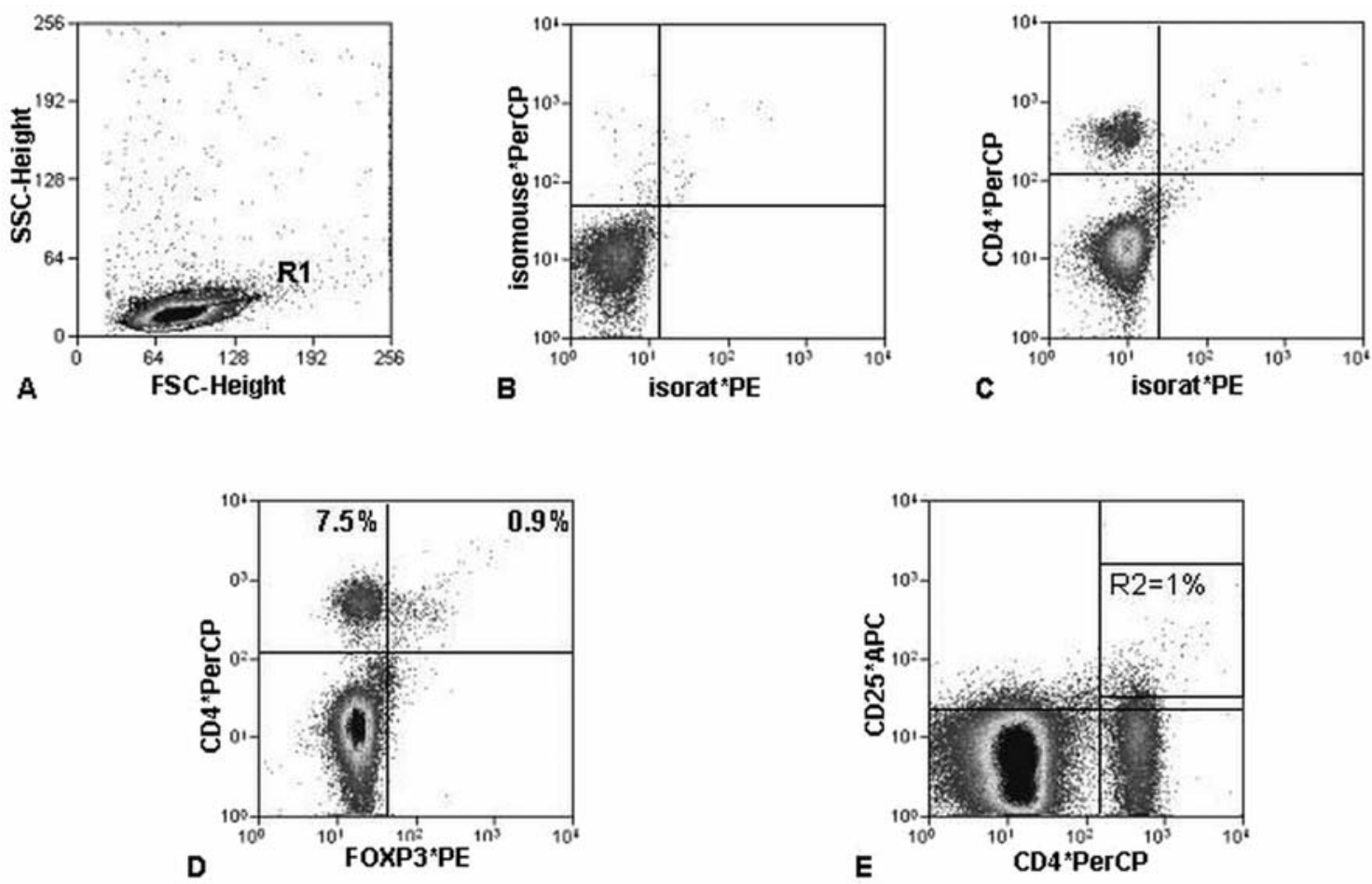

Figure 1. Four color-staining of $\mathrm{CD} 4{ }^{+} \mathrm{CD} 25^{\text {hiFOXP3 }}{ }^{+} \mathrm{T}$ regulatory cells in B-CLL patients. The lymphocyte subpopulation was gated (R1) based on forward vs. side scatter (FSC/SSC) characteristics (A). Compared to the isotype (B) and FMO (Fluorescence Minus One) (C) controls, the intracellular expression of FOXP3 was evaluated in $\mathrm{CD} 4^{+} \mathrm{T}$ cells $(\mathrm{D})$. This gating strategy was compared to the expression of $\mathrm{CD}^{+} \mathrm{CD} 25^{\mathrm{hi}} \mathrm{T}$ cells $(\mathrm{E})$. All cells gated as $\mathrm{CD} 4^{+} \mathrm{FOXP} 3^{+}$were $\mathrm{CD} 25^{\mathrm{hi}}$.

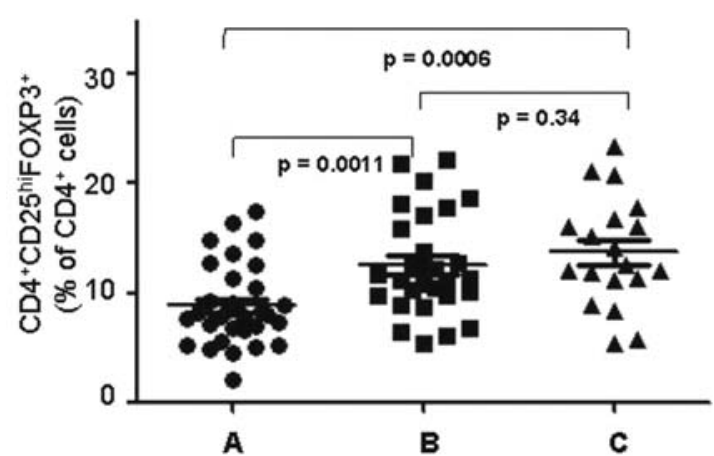

Figure 2. The frequency of Treg in B-CLL increases with the stage of the disease. The median frequency of Treg was compared between groups of B-CLL patients at different stages (according to the Binet classification).

Thereafter, cells were washed twice in PBS containing 2\% FCS (Biochrom AG) and were counted. The staining of the surface antigens CD4, CD8 and CD25 was performed after the incubation of $1 \times 10^{6}$ cells with antibodies, according to the manufacturer's protocols (BD Biosciences, Mannheim, Germany). Cells were then permeabilized, blocked with rat serum and stained with an anti-FOXP3 rat monoclonal antibody according to manufacturer's protocols (eBioscienes, San Diego, CA, USA). After the intracellular staining, cells were washed twice and analyzed by flow cytometry for the expression of FOXP3 and CD25 on $\mathrm{CD}^{+}$cells. At least 100,000 cells were collected and analyzed.

Evaluation of TNF receptor 1 (TNF R1) and R2 expression. Expression of TNF R1 and R2 was performed by FACS analysis, as described previously in detail (26).
ELISA for the tumor necrosis factor (TNF) and soluble HLA-G. In $20 \mathrm{~B}-\mathrm{CLL}$ patients, the TNF level in the serum was determined by human TNF- $\alpha$ Quantikine HS ELISA (R\&D Systems, USA) according to manufacturer's protocols. The serum level of sHLA-G was assessed by using sHLA-G ELISA (BioVendor Laboratory Medicine, Czech Republic) according to manufacturer's protocols.

Statistical analysis. The results are presented as median values. The Mann-Whitney U test was used to evaluate differences between analyzed subgroups of patients and HV. Linear regression was used to access the correlation between age, lymphocyte count, TNF serum level and Treg frequency.

\section{Results}

The frequency of Treg increased with the stage of the disease. In B-CLL patients, we identified the subpopulation of $\mathrm{CD} 4{ }^{+} \mathrm{CD} 25^{\text {hiFOXP }} 3^{+} \mathrm{T}$ cells as regulatory $\mathrm{T}$ cells (Treg) (Fig. 1). The median frequency of Treg was significantly higher in B-CLL patients when compared to HV (10.59 vs. $1.9 \%, \mathrm{p}=0.0001$ ). The progressive increase of Treg was noted in the advanced stages of the disease. A median percentage of Treg for CLL patients in stage A was 8.24\%, 11.24\% in stage $\mathrm{B}$ and $12.57 \%$ in stage $\mathrm{C}$ according to the Binet classification (Fig. 2).

Correlation of Treg with age and prognostic factors. No correlation between the percentage of Treg and ZAP-70 status was observed. A tendency to higher frequencies in ZAP-70 negative patients was noted 11.1 vs. $8.85 \%(\mathrm{p}=0.32)$. Similarly, there was a tendency for higher percentages of Treg in patients 


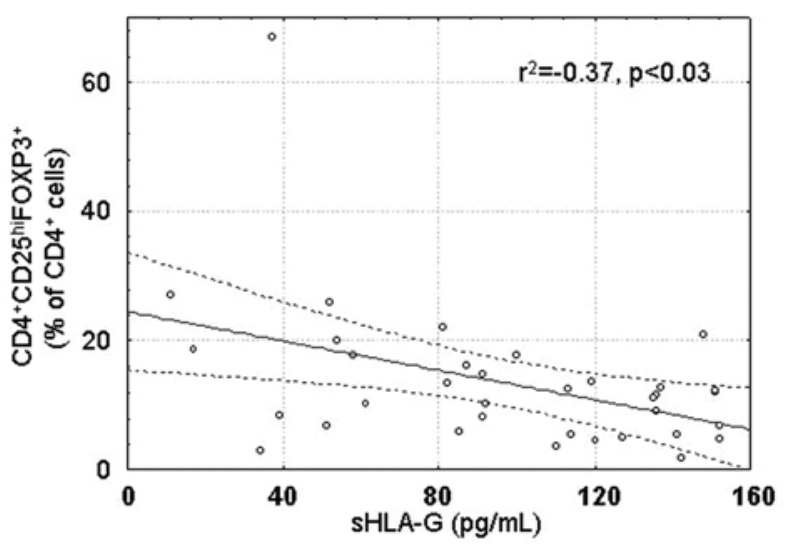

Figure 3. Inverse correlation between Treg frequency and the serum level of soluble HLA-G (sHLA-G). Treg were identified by flow cytometry as shown in Fig. 1. The frequency of Treg was calculated as $\mathrm{CD} 4{ }^{+} \mathrm{CD} 25^{\text {hi }} \mathrm{FOXP} 3^{+}$ among $\mathrm{CD} 4^{+} \mathrm{T}$ cells. Thereafter, the percentages of Treg were correlated with the levels of soluble HLA-G assessed by ELISA. Treg showed an inverse correlation with sHLA-G in B-CLL patients $\left(\mathrm{r}^{2}=-0.37, \mathrm{p}<0.03, \mathrm{n}=36\right)$.

who were CD38 (-) (10.3 vs. 9.96\% p=0.88). No correlation of Treg frequency and lymphocyte count or age of patients was noted $\left(\mathrm{r}^{2}=0.079, \mathrm{p}=0.029\right)$.

Treg increased with respect to TNF serum levels. Higher frequencies of Treg were observed in CLL patients with higher levels of TNF serum $\left(\mathrm{r}^{2}=0.45, \mathrm{p}=0.001, \mathrm{n}=20\right)$. No correlation between the frequency of Treg and the expression of TNF receptor 1 (TNFR1, $n=40)$ or TNFR2 $(n=40)$ was observed.

Treg correlated inversely with serum levels of HLA-G. An inverse correlation between the frequency of Treg and the serum level of soluble HLA-G (sHLA-G) was observed $\left(r^{2}=-0.37, p<0.03, n=36\right.$, Fig. 3). The surface expression of HLA-G molecules in CD5 ${ }^{+} \mathrm{CD} 19^{+}$CLL cells tended to be lower in patients with higher percentages of Treg $\left(r^{2}=-0.23\right.$, $\mathrm{p}=\mathrm{NS}, \mathrm{n}=20$ ).

Correlation of Treg frequencies and the T-cell responses in ELISpot assays. Higher frequencies of Treg correlated with a significantly lower secretion of IFN- $\gamma$ against tumor and viral antigens (Fig. 4, cut off $=10.5 \%$, calculated in the median frequency of Treg). Patients with lower frequencies of Treg displayed preserved T-cell function. The results from an ELISpot assay of a CLL patient is shown in Fig. 5.

\section{Discussion}

The human immune system develop mechanisms, which eliminate pathogens as well as protect the organism from self-destruction. In the control of immunosurveillance, the so-called 'natural' regulatory $\mathrm{T}$ cells (Treg) play a pivotal role (15). However, the definition of 'natural' Treg is a matter of debate. Markers such as CD25, GITR and CD62L were tested by FACS analysis, although only the intracellular staining of FOXP3, the specific transcription factor of Treg, defines a distinct population of Treg (Fig. 1). In B-CLL, we identified a population of Treg $\left(\mathrm{CD} 4{ }^{+} \mathrm{CD} 25^{\mathrm{hi}} \mathrm{FOXP} 3^{+}\right)$at frequencies increasing with the stage of the disease (Fig. 2). Moreover, these Treg were functionally able to abrogate $\mathrm{T}$ cell responses against TAA and viral antigens (Fig. 4). Several studies have shown the inhibitory properties of Treg in immunosuppressive assays, where a single agent was added to inhibit the immune effect of a mixed lymphocyte reaction $(8,15,16)$. In this study, we showed for the first time that in a complex system of peripheral blood mononuclear cells Treg played a crucial role in the modulation of the immune response against tumor and viral antigens, which underlines the clinically well known immunodeficient status of advanced B-CLL patients through the excess of Treg.

Previously, Amiot et al (27) found that an increased mRNA level of HLA-G mostly resulted in increased serum

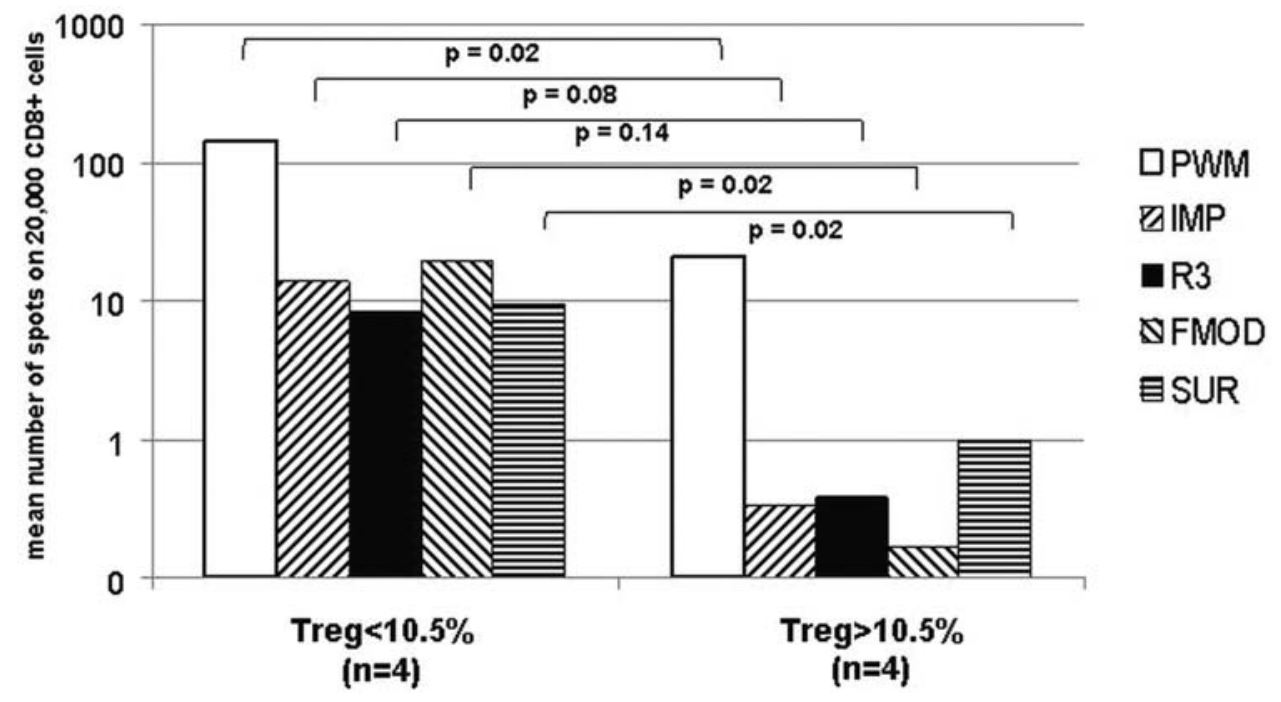

Figure 4. T-cell responses against tumor and viral antigens depend on Treg frequencies in peripheral blood mononuclear cells of B-CLL. Specific CTL responses against peptides derived from the tumor-associated antigens RHAMM (R3), fibromodulin (FMOD) and survivin (SUR) as well as the viral peptide-influenza matrix protein (IMP) were assessed by ELISpot assay for the secretion of IFN- $\gamma$ in peripheral blood mononuclear cells (PBMC) of B-CLL patients after 7 days of mixed lymphocyte peptide culture. The lectin pokeweed mitogen (PWM) served as a positive control. Results were normalized against CD8+ $\mathrm{T}$ cells and were displayed as the mean number of spots on $20,000 \mathrm{CD}^{+}$cells. Results are compared for two groups of patients with less or more than $10.5 \%$ of Treg. 

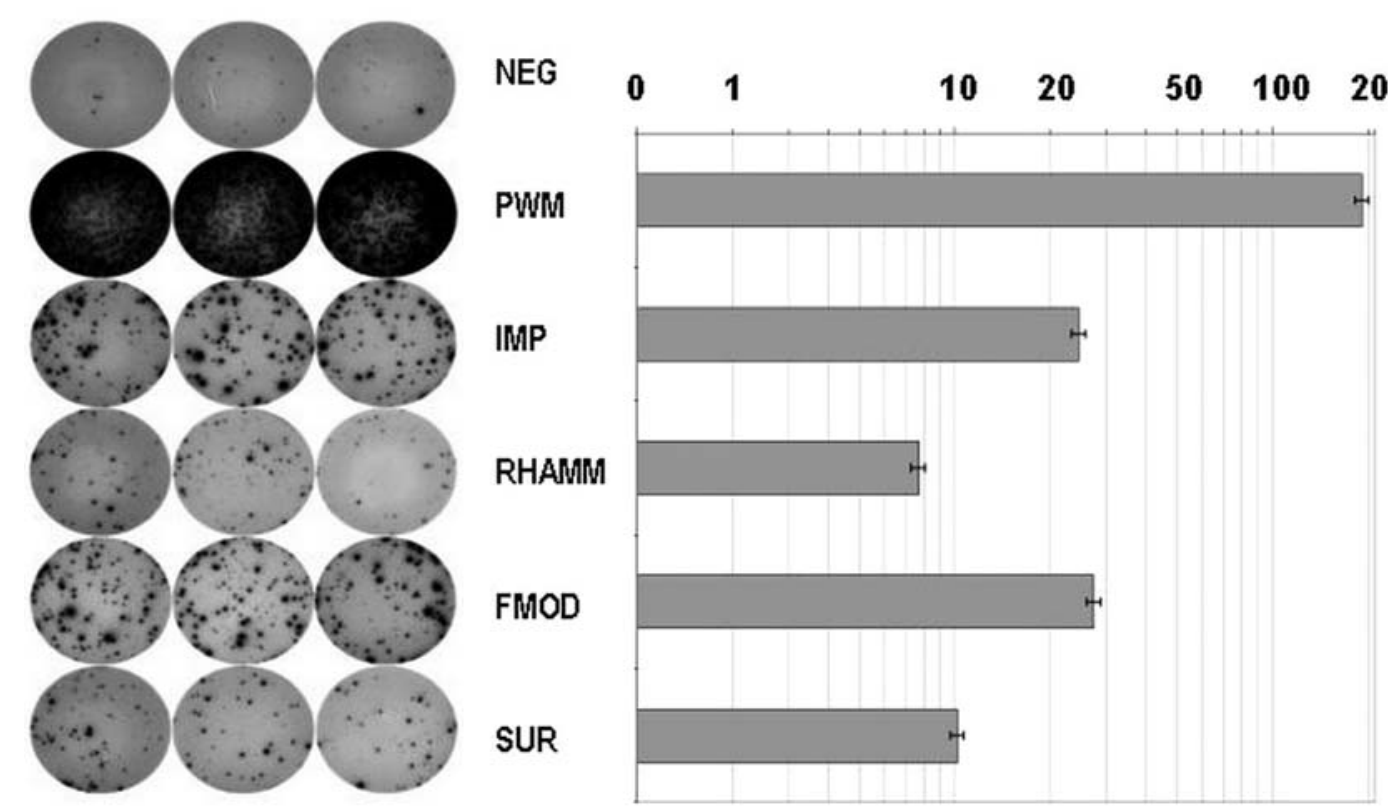

Figure 5. ELISpot assay for IFN- $\gamma$ secretion by CD8+ T cells from PBMC of a B-CLL patient. Specific CTL responses against the tumor-associated antigens RHAMM (R3), fibromodulin (FMOD) and survivin (SUR) as well as against the viral influenza matrix protein (IMP) in one B-CLL patient after 7 days of mixed lymphocyte peptide culture as assessed by ELISpot assay for IFN- $\gamma$ secretion. Numbers indicate the mean value of spots in triplicate per 20,000 CD $8^{+}$cells. The lectin pokeweed mitogen (PWM) served as a positive control. Results were normalized against the number of spots in a negative control (NEG), i.e. mean values of the background were subtracted from values specific for each experiment.

levels of soluble HLA-G (sHLA-G), though in a hardly increased expression of HLA-G molecules on the cell surface. In the current study, we observed no correlation between Treg and the expression of surface HLA-G. Notably, an inverse correlation between sHLA-G and Treg was found. Amiot et al (27) reported that increased levels of soluble HLA-G in BCLL patients might favor the progression of the disease by the inhibition of the T-cell function (12). The results of this study suggest that Treg represent a major mechanism, which is responsible for immunosuppression when compared with HLA-G since T-cell responses in the complex system of PBMC rely on the frequency of Treg, though not HLA-G.

We evaluated Treg frequency in CLL patients with a different prognosis since the increased Treg frequency may represent the main immune mechanism responsible for disease progression in CLL. It is noteworthy that CLL patients with an unfavorable prognosis showed slightly lower percentages of Treg. Treg frequency correlated neither with the expression of ZAP-70 nor with the expression of CD38. Moreover, no correlation of Treg frequency with HLA-G expression was found. HLA-G was reported as a surrogate prognostic marker in B-CLL, superior to ZAP-70 as well as CD38 (11).

The definition of TAA-derived immunogenic epitopes represents a cornerstone for peptide-based immunotherapies. With respect to design, the novel peptide vaccination trials in B-CLL, there is a fervent need to define and add some components which might inhibit Treg in order to induce a Tcell-mediated rejection of CLL cells. However, it is still unclear which factor promotes Treg proliferation.

Elevated levels of TNF were associated with progressive disease in patients with B-CLL and increased with the stage of the disease (22). Here, a correlation between the percentages of Treg and TNF serum levels was observed. This might suggest a promotion of Treg through TNF. Patients with an increased frequency of Treg and elevated levels of TNF displayed an impaired responsiveness against tumor and viral antigens. However, no correlation to the expression of TNF receptors was found. Conversely, TNF was reported to downregulate the suppressive function of Treg (21). Elevated serum concentrations of TNF are present in various pre-neoplasmic and malignant diseases, when compared with serum TNF levels detected in healthy individuals (28). An increased number of Treg was also reported in several malignancies. Possibly, increased TNF levels promote Treg proliferation. Nonetheless, the results of our study suggest that TNF is unable to block the suppressive activity of Treg in B-CLL. Anti-TNF treatment of RA patients with infliximab upregulated the function of Treg (21). We reported earlier on a specific decrease in the Treg number in B-CLL patients treated with thalidomide, which therapeutical anti-TNF effect is known (29). The ambiguous effect of TNF in RA and CLL patients suggests that several other mechanisms are involved in the regulation of Treg function.

In summary, an increased expression of FOXP3 ${ }^{+}$Treg in B-CLL patients was found. The percentage of Treg increased along with the stage of the disease. Increased frequencies of Treg were functionally able to inhibit $\mathrm{T}$-cell responses against TAA and viral antigens. These functional studies underline the pivotal role of Treg in the restriction of T-cell responses in the peripheral blood from B-CLL patients.

\section{Acknowledgements}

This study was supported by grants from the Polish Scientific Committee KBN N40203431/1138 and N40210732/3496 as well as from the Else Kröner-Fresenius-Foundation A85/06. Krzysztof Giannopoulos was supported by a generous scholarship from the Foundation for Polish Science. 


\section{References}

1. Ravandi $\mathrm{F}$ and $\mathrm{O}$ 'Brien S: Immune defects in patients with chronic lymphocytic leukemia. Cancer Immunol Immunother 55: 197-209, 2006.

2. Giannopoulos K and Schmitt M: Targets and strategies for T-cell based vaccines in patients with B-cell chronic lymphocytic leukemia. Leuk Lymphoma 47: 2028-2036, 2006.

3. Ghia P, Scielzo C, Frenquelli M, Muzio M and Caligaris-Cappio F: From normal to clonal B cells: chronic lymphocytic leukemia (CLL) at the crossroad between neoplasia and autoimmunity. Autoimmun Rev 7: 127-131, 2007.

4. Mellstedt $\mathrm{H}$ and Choudhury A: T and B cells in B-chronic lymphocytic leukaemia: Faust, Mephistopheles and the pact with the Devil. Cancer Immunol Immunother 55: 210-220, 2006.

5. Ritgen M, Stilgenbauer S, von Neuhoff N, Humpe A, Bruggemann M, Pott C, Raff T, Krober A, Bunjes D, Schlenk R, Schmitz N, Döhner H, Kneba M and Dreger P: Graft-versusleukemia activity may overcome therapeutic resistance of chronic lymphocytic leukemia with unmutated immunoglobulin variable heavy-chain gene status: implications of minimal residual disease measurement with quantitative PCR. Blood 104: 2600-2602, 2004.

6. Tsiodras S, Samonis G, Keating MJ and Kontoyiannis DP: Infection and immunity in chronic lymphocytic leukemia. Mayo Clin Proc 75: 1039-1054, 2000.

7. Gitelson E, Hammond C, Mena J, Lorenzo M, Buckstein R, Berinstein NL, Imrie K and Spaner DE: Chronic lymphocytic leukemia-reactive $\mathrm{T}$ cells during disease progression and after autologous tumor cell vaccines. Clin Cancer Res 9: 1656-1665, 2003.

8. Beyer M, Kochanek M, Darabi K, Popov A, Jensen M, Endl E, Knolle PA, Thomas RK, von Bergwelt-Baildon M, Debey S, Hallek M and Schultze JL: Reduced frequencies and suppressive function of $\mathrm{CD} 4{ }^{+} \mathrm{CD} 25 \mathrm{hi}$ regulatory $\mathrm{T}$ cells in patients with chronic lymphocytic leukemia after therapy with fludarabine. Blood 106: 2018-2025, 2005.

9. Fayad L, Keating MJ, Reuben JM, O'Brien S, Lee BN, Lerner S and Kurzrock R: Interleukin-6 and interleukin-10 levels in chronic lymphocytic leukemia: correlation with phenotypic characteristics and outcome. Blood 97: 256-263, 2001.

10. Lotz M, Ranheim E and Kipps TJ: Transforming growth factor beta as endogenous growth inhibitor of chronic lymphocytic leukemia B cells. J Exp Med 179: 999-1004, 1994.

11. Nuckel H, Rebmann V, Durig J, Duhrsen U and Grosse-Wilde H: HLA-G expression is associated with an unfavorable outcome and immunodeficiency in chronic lymphocytic leukemia. Blood 105: 1694-1698, 2005.

12. Contini P, Ghio M, Poggi A, Filaci G, Indiveri F, Ferrone S and Puppo F: Soluble HLA-A,-B,-C and $-\mathrm{G}$ molecules induce apoptosis in $\mathrm{T}$ and $\mathrm{NK} \mathrm{CD}^{+}$cells and inhibit cytotoxic $\mathrm{T}$ cell activity through CD8 ligation. Eur J Immunol 33: 125-134, 2003.

13. Kono K, Kawaida H, Takahashi A, Sugai H, Mimura K, Miyagawa N, Omata H and Fujii H: CD4(+)CD25(high) regulatory $\mathrm{T}$ cells increase with tumor stage in patients with gastric and esophageal cancers. Cancer Immunol Immunother 55: 1064-1071, 2006.

14. Li X, Ye DF, Xie X, Chen HZ and Lu WG: Proportion of $\mathrm{CD} 4{ }^{+} \mathrm{CD} 25^{+}$regulatory $\mathrm{T}$ cell is increased in the patients with ovarian carcinoma. Cancer Invest 23: 399-403, 2005.

15. O'Garra A and Vieira P: Regulatory T cells and mechanisms of immune system control. Nat Med 10: 801-805, 2004.

16. Miller AM, Lundberg K, Ozenci V, Banham AH, Hellstrom M, Egevad L and Pisa P: CD ${ }^{+} \mathrm{CD} 25$ high T cells are enriched in the tumor and peripheral blood of prostate cancer patients. J Immunol 177: 7398-7405, 2006.
17. Ziegler SF: FOXP3: of mice and men. Annu Rev Immunol 24: 209-226, 2006.

18. Giannopoulos K, Li L, Bojarska-Junak A, Rolinski J, Dmoszynska A, Hus I, Greiner J, Renner C, Dohner H and Schmitt M: Expression of RHAMM/CD168 and other tumorassociated antigens in patients with B-cell chronic lymphocytic leukemia. Int J Oncol 29: 95-103, 2006.

19. Mayr C, Bund D, Schlee M, Moosmann A, Kofler DM, Hallek M and Wendtner CM: Fibromodulin as a novel tumor-associated antigen (TAA) in chronic lymphocytic leukemia (CLL) which allows expansion of specific $\mathrm{CD} 8^{+}$autologous $\mathrm{T}$ lymphocytes. Blood 105: 1566-1573, 2005

20. Müller MR, Tsakou G, Grunebach F, Schmidt SM and Brossart P: Induction of chronic lymphocytic leukemia (CLL)-specific CD4- and CD8-mediated T-cell responses using RNA-transfected dendritic cells. Blood 103: 1763-1769, 2004.

21. Valencia X, Stephens G, Goldbach-Mansky R, Wilson M, Shevach EM and Lipsky PE: TNF downmodulates the function of human $\mathrm{CD}^{+} \mathrm{CD} 25$ hi T-regulatory cells. Blood 108: 253-261, 2006.

22. Ferrajoli A, Keating MJ, Manshouri T, Giles FJ, Dey A, Estrov Z, Koller CA, Kurzrock R, Thomas DA, Faderl S, Lerner S, O'Brien S and Albitar M: The clinical significance of tumor necrosis factor-alpha plasma level in patients having chronic lymphocytic leukemia. Blood 100: 1215-1219, 2002.

23. Greiner J, Li L, Ringhoffer M, Barth TF, Giannopoulos K, Guillaume P, Ritter G, Wiesneth M, Dohner H and Schmitt M: Identification and characterization of epitopes of the receptor for hyaluronic acid-mediated motility (RHAMM/CD168) recognized by $\mathrm{CD} 8^{+} \mathrm{T}$ cells of HLA-A2-positive patients with acute myeloid leukemia. Blood 106: 638-645, 2005.

24. Greiner J, Ringhoffer M, Simikopinko O, Szmaragowska A, Huebsch S, Maurer U, Bergmann L and Schmitt M: Simultaneous expression of different immunogenic antigens in acute myeloid leukemia. Exp Hematol 28: 1413-1422, 2000.

25. Britten CM, Gouttefangeas C, Welters MJ, Pawelec G, Koch S, Ottensmeier C, Mander A, Walter S, Paschen A, MüllerBerghaus J, Haas I, Mackensen A, Køllgaard T, thor Straten P, Schmitt M, Giannopoulos K, Maier R, Veelken H, Bertinetti C, Konur A, Huber C, Stevanovic S, Wölfel T and van der Burg SH: The CIMT-monitoring panel: a two-step approach to harmonize the enumeration of antigen-specific $\mathrm{CD} 8^{+} \mathrm{T}$ lymphocytes by structural and functional assays. Cancer Immunol Immunother 57: 289-302, 2008.

26. Bojarska-Junak A, Hus I, Szczepanek EW, Dmoszynska A and Rolinski J: Peripheral blood and bone marrow TNF and TNF receptors in early and advanced stages of B-CLL in correlation with ZAP-70 protein and CD38 antigen. Leuk Res (In press).

27. Amiot L, Le Friec G, Sebti Y, Drénou B, Pangault C, Guilloux V, Leleu X, Bernard M, Facon T and Fauchet R: HLA-G and lymphoproliferative disorders. Semin Cancer Biol 13: 379-385, 2003.

28. Szlosarek P, Charles KA and Balkwill FR: Tumour necrosis factor-alpha as a tumour promoter. Eur J Cancer 42: 745-750, 2006.

29. Giannopoulos K, Schmitt M, Wlasiuk P, Chen J, Bojarska-Junak A, Kowal M, Rolinski J and Dmoszynska A: The high frequency of $\mathrm{T}$ regulatory cells in patients with B-cell chronic lymphocytic leukemia is diminished through treatment with thalidomide. Leukemia 22: 222-224, 2008. 